outside London that they must prepare schemes in order to secure the payment of annual contributions towards the expenses of such voluntary associations within their areas, copies of model schemes for their use being enclosed with the Circular. Respecting venereal diseases, the Minister of Health has issued circulars (1536 and $1536 a$ ) to the responsible port and local authorities in England and Wales enclosing a revised list of treatment centres in the chief sea and river ports throughout the world at which seamen can obtain gratuitous treatment for these diseases, in accordance with arrangements contemplated by the international agreement signed at Brussels in 1924.

\section{The Lister Institute of Preventive Medicine}

THE Annual General Meeting of this Institute was held on June 9, and the Governing Body presented the forty-second Annual Report, in which the activities of the Institute are surveyed. Investigations have been carried out upon vaccinia, tumour-exciting, neurotropic and other virus agents by the director, Prof. J. C. G. Ledingham, and Dr. E. W. Hurst, Dr. C. R. Amies and others. Various serological studies are being continued by Dr. A. Felix and collaborators. Dr. V. Korenchevsky is continuing his work on sexual hormones, and Prof. R. Robison with others is studying phosphate metabolism and tissue calcification. Investigations on rheumatism and the possible presence of a virus agent in this disease are being pursued by Dr. Amies and colleagues in conjunction with King's College Hospital. In the Division of Nutrition, much work upon vitamins and dietary constituents has been carried out by Dr. Harriette Chick and her associates. The Svedberg ultra-centrifuge, referred to in last year's Report, with accessory equipment is now in course of installation. At the Serum Department at Elstree, under Dr. G. F. Petrie, to which the Vaccine Department has now been transferred, work on meningococcus and gas-gangrene anti-sera and on staphylococcus toxin is in progress. This brief and incomplete survey illustrates the important research work now being carried on at the Lister Institute.

\section{Experimental Research and Disease}

THE tenth Stephen Paget Memorial Lecture was delivered by Sir Malcolm Watson at the annual general meeting of the Research Defence Society, held at the London School of Hygiene and Tropical Medicine on June 9, the president, Lord Lamington, occupying the chair (The Fight against Disease, 24, No. 3,1936$)$. In order to illustrate the importance of experimental research, Sir Malcolm surveyed the work of Manson upon elephantiasis and filarial periodicity and malaria, of Ross upon malaria and its transmission by mosquitoes, and of Reed upon yellow fever. By applying the knowledge won by Walter Reed and his American colleagues, the city of Havana was within a few months freed from yellow fever for the first time in a hundred and fifty years by exterminating the mosquitoes that convey the disease. Owing to an increase in member's and life- member's subscriptions for 1935, the Research Defence Society has commenced the current year with a small balance in hand.

\section{A New Anthropological Publication}

A NEw publication of the Section of Anthropology of the Department of the Social Sciences of Yale University, entitled "Yale University Publications in Anthropology", has appeared, which will embody the results of researches in the general field of anthropology directly conducted or otherwise sponsored by this Department of the Graduate School, the Department of Anthropology of the Peabody Museum, and the Department of Anthropology of the Institute of Human Relations (Yale University Press, New Haven, Conn.; London: Oxford University Press). The issues, which will range from brief papers to extensive monographs, will be numbered consecutively as independent contributions, and will appear at irregular intervals. The first issue (Nos. 1-7) includes a study of population changes among the northern Plains Indians by Dr. Clark Wissler, an examination of regional diversity in sorcery in Polynesia by Dr. P. H. Buck, an account of cultural relations of the Gila River and Lower Colorado tribes by Dr. Leslie Spier, with several other communications dealing with aspects of the culture of the Indians of North America. A further issue of the publication, which will comprise six communications, is in the press. In view of the widespread activities in anthropological research of the institutions interested in this publication, and more especially of Yale University, the facilities which it will afford for early publication of results will be of great advantage to anthropologists. In this connexion, it may not be out of place to refer to the announce. ment that Dr. David G. Mandelbaum of Yale, who has hitherto specialized in the culture of the North American tribes, will be engaged during the coming year in an investigation among the hill tribes of Southern India.

\section{History of Fire-Fighting in America}

IN a paper received from the Smithsonian Institution, a brief history is given of fire-fighting in America from colonial days to the present time. It starts with the days of the 'bucket brigades'. Many of the earliest American communities required property owners to have fire buckets in their houses, which they had to throw into the street when a fire alarm was sounded. They were then picked up by the men who raced to the fire, and when the fire was extinguished these buckets were piled up on the village common, where the owners came to claim them. In an exhibition being held in the National Museum in Washington, many of these buckets are shown. They are made of leather, and in addition to the names of the owners are decorated with family devices and scenes of the time. The first hand-pumped fire engine or tub, made in 1740, is on exhibition; but the bucket brigades were still necessary in order to fill it with water. These tubs were pulled by hand, and at night runners went before them carrying torches or lanterns 